ORIGINAL ARTICLE / ARTIGO ORIGINAL

\title{
Violence against women and its
} association with the intimate partner's profile: a study with primary care users

\author{
Violência contra a mulher e sua associação com o \\ perfil do parceiro intimo: estudo com usuárias da atenção primária
}

\author{
Franciéle Marabotti Costa Leite' (D), Mayara Alves Luis' (D), Maria Helena Costa Amorim' (D), \\ Ethel Leonor Noia Maciel' (D), Denise Petrucci Gigante"
}

\begin{abstract}
Objective: To verify the association between the history of violence against women and the sociodemographic and behavioral characteristics of intimate partners. Methods: A cross-sectional study was carried out with 938 women using basic health care, aged between 20 and 59 years, who at the time of the interview had an intimate partner. Information about the sociodemographic and behavioral characteristics of the intimate partner were collected, as well as the WHO VAW Study instrument for tracking the psychological, physical and sexual violence experienced in the past year. A bivariate analysis was performed using the Pearson $\mathrm{c}^{2}$ test and multivariate analysis using Poisson regression with robust variance. Results: The highest prevalences of psychological, physical and sexual violence were significantly associated with partners who had no occupation and who refused to use condoms in sexual relationships. Men who were considered controllers and who consumed alcoholic beverages were associated with greater perpetration of psychological and physical violence $(p<0.05)$. Partners with up to eight years of schooling present a higher frequency of psychological violence $(\mathrm{PR}=1.32,95 \% \mathrm{CI} 1.05-1.66)$, while sexual violence was significantly higher among women whose partners smoked: 1.94, 95\%CI $1.11-3.38)$. Conclusions: These data highlight the importance of health professionals, work together in other sectors such as education and safety, dealing with alcohol and other drugs, as well as addressing issues of gender.
\end{abstract}

Keywords: Violence. Domestic violence. Violence against women. Intimate partner violence. Spouse abuse.

INursing Department, Universidade Federal do Espírito Santo - Vitória (ES), Brazil.

"Nutrition Department, Universidade Federal de Pelotas - Pelotas (RS), Brazil.

Corresponding author: Franciéle Marabotti Costa Leite. Departamento de Enfermagem, Universidade Federal do Espírito Santo. Avenida Marechal Campos, 1.468, Maruípe, CEP: 29040-090,| Vitória (ES), Brasil. E-mail: francielemarabotti@gmail.com Conflict of interests: nothing to declare - Financing source: Fundação de Amparo à Pesquisa e Inovação do Espírito Santo (FAPES - Process No. 60530812/12). 
RESUMO: Objetivo: Verificar associação entre a história de violência contra a mulher e características sociodemográficas e comportamentais do parceiro íntimo. Métodos: Estudo transversal realizado com 938 mulheres usuárias da atenção básica de saúde, com idade entre 20 e 59 anos e que no momento da entrevista possuíam parceiro íntimo. Foram coletadas informações sobre as características sociodemográficas e comportamentais, do parceiro íntimo, bem como foi aplicado o instrumento World Health Organization Violence Against Woman (WHO VAW Study) para o rastreamento da violência psicológica, física e sexual vivenciada no último ano. Foi realizada análise bivariada, por meio do teste do $c^{2}$ de Pearson, e multivariada usando regressão de Poisson com variância robusta. Resultados: As maiores prevalências de violência psicológica, física e sexual estiveram significativamente associadas aos parceiros que não possuíam ocupação e que recusaram o uso do preservativo nas relações sexuais. Homens que foram considerados controladores e que ingeriam bebida alcoólica estiveram associados a maior perpetração de violência psicológica e física $(\mathrm{p}<0,05)$. Parceiros com até 8 anos de escolaridade apresentam maior frequência de prática de violência psicológica ( $R P=1,32$; IC95\% 1,05 - 1,66), enquanto a violência sexual foi significativamente maior entre as mulheres cujos parceiros fumavam ( $R P=1,94$; IC95\% 1,11-3,38). Conclusões: Esses dados evidenciam a importância de os profissionais de saúde atuarem juntamente a outros setores, tais como educação e segurança, no enfrentamento ao álcool e outras drogas, bem como na abordagem das questões de gênero.

Palavras-chave: Violência. Violência doméstica. Violência contra a mulher. Violência por parceiro íntimo. Maustratos conjugais.

\section{INTRODUCTION}

Violence against women is a complex social phenomenon associated with psychological, moral and physical harm. Its manifestations are ways of establishing a relationship of subordination, always culminating in circumstances of fear, isolation, dependence and intimidation for women. It is understood as an action that embraces one's use of real or symbolic force, with the intention of dominating one's body and mind at the will and freedom of others ${ }^{1}$.

Inequality of power in relations is the central issue of the phenomenon of violence. Oppression is a way of exercising dominant patriarchal power while at the same time perpetuating the inequities of power expressed in unequal gender relations ${ }^{2}$. It should be noted that violence against women has been indiscriminately committed, especially in the family environment, whose invisibility is favored by its occurrence in private spaces ${ }^{3}$. The intimate partner stands out as one of its main perpetrators. In this context, women experience relationships based on aggressive behaviors by their partner, which culminates in physical, sexual or psychological harm, and may also be accompanied by controlling behaviors.

According to the World Health Organization (WHO), 35\% of women worldwide have already suffered physical and/or intimate partner violence 5 . In Brazil, a population-based study showed that $43 \%$ of Brazilian women reported having suffered violence by a man in their lives; one third admitted to having suffered some form of physical violence, $13 \%$ sexual and $27 \%$ psychological ${ }^{6}$. A study conducted in Vitória, Espírito Santo, showed that in 
the year prior to the interview, 1 in 10 women had experienced situations of physical violence committed by their partner ${ }^{7}$.

It is important to highlight that the literature shows the highest occurrence of violence among women whose partners are unemployed, have low education, are users of alcohol and drugs and witnessed violence in the family ${ }^{8}$. In addition, jealousy crises have emerged as a cause of violence against women, making it clear how cultural and gender issues are associated with the perpetration of this problem ${ }^{9}$.

Thus, considering the magnitude of violence against women, and that the intimate partner is one of the main aggressors, the study of the characteristics of those who practice violence is an important tool that will contribute to the elaboration of strategies to confront violence, focused on preventive actions. Given the above, this study aimed to verify the association between the history of violence against women and sociodemographic and behavioral characteristics of the intimate partner.

\section{METHOD}

Cross-sectional study conducted between March and September 2014, in 26 health units in the municipality of Vitória, Espírito Santo. Data from women aged 20 to 59 years old who had an intimate partner at the time of collection were used. It was defined as intimate partner the life partner, or former partner, regardless of formal marriage and current boyfriends, provided that they were currently engaged in having sex.

This study is part of a larger research, ${ }^{7}$ in which the sample size calculation considered 95\% confidence level, $80 \%$ power and 1:1 exposed/ unexposed ratio. Total sample consisted of 998 participants, with the addition of $10 \%$ for possible losses and $30 \%$ for adjusted analyses. For the present study, we chose to work only with data from women who at the time of the interview had an intimate partner, thus constituting 938 participants.

During data collection two forms were applied. The first was designed to identify the independent variables of the study, that is, the sociodemographic and behavioral characteristics of the partner. As sociodemographic variables, women were asked about: age of partner (in complete years and categorized up to 40 years old or over 40 years old); race / color (white, black or brown); education (in complete years of study and categorized into up to 8 years or more than 8 years of study); and if the partner had a paid occupation (yes or no). Regarding the behavioral variables of the partner, the form presented as questions: current use of illicit drugs (yes or no); smoke at least one cigarette per day (yes or no); current alcohol use (yes or no); partner is the controller type (yes or no); partner is jealous (yes or no) and if the partner ever during sex refused to use a condom (yes or no).

To identify the outcomes, the intimate partner's psychological, physical and sexual violence against women within the last 12 months was applied to the World Health Organization Violence Against Woman (WHO VAW STUDY) instrument, consisted of 13 questions and is able to discern the forms of violence in different social contexts. This instrument has a 
high internal consistency, presented by Cronbach's coefficients (mean of 0.88$)^{10}$. It is worth mentioning that the interview was conducted individually, by trained interviewers, and only after signing the Informed Consent Form.

The data produced were analyzed using the STATA 13.0 statistical package. The Pearson $\mathrm{c}^{2}$ test was used in the bivariate analyses. Multivariable analysis to investigate the associations of possible confounders with exposure and outcome was performed using Poisson regression with robust variance. The variables were entered in the model hierarchically according to the following levels: distal (age, race/color, education and paid occupation), intermediate (current drug use, smoking and alcohol use), proximal (controller, jealous and refusal to condom use during sex $)^{11}$. The entry, according to the hierarchical model, occurred if $\mathrm{p}$ $<0.20$, by backward selection, and permanence in the model if $\mathrm{p}<0.05$. Prevalence ratio was used as a measure of effect.

The study was approved by the Research Ethics Committee of the Federal University of Espírito Santo (Universidade Federal do Espirito Santo - UFES), Opinion No. 470.744.

\section{RESULTS}

Among the 938 studied subjects, most partners were aged under 40 years old (52.4\%), about $40.0 \%$ were brown, $66.1 \%$ had more than 8 years of study and almost $87.0 \%$ had occupation. Regarding behavioral profile, according to the interviewees, $6.3 \%$ of partners used illicit drugs and approximately $19.0 \%$ smoked. Alcohol intake was reported by $57.8 \%$. For women, $53.0 \%$ of their partners were jealous and $48.2 \%$ controllers. Regarding condom use, $24.0 \%$ had already refused to use it during sex (Table 1 ).

In the last 12 months, psychological - with prevalence (P) of $24.8 \%$ with $(95 \% \mathrm{CI}$ $22.2-27.7)-$, sexual $(\mathrm{P}=5.33 \%$; 95\%CI $4.1-7.0)$ and physical $(\mathrm{P}=9.28 \%$; $95 \% \mathrm{CI}$ $7.6-11.3$ ) violence were present among the study participants (data not shown in table). Table 2 shows that the experience of psychological and physical violence was more prevalent among women whose partners had up to eight years of study, had no occupation, used drugs, smoked, drank alcohol, were considered jealous or controlling by the woman and had a history of refusal to use condoms during sex $(\mathrm{p}<0.05)$. Regarding sexual violence, this was more frequent among those whose partners were over 40 years old, had no occupation, smoked and refused to use condoms $(\mathrm{p}<0.05)$.

Table 3 presents the crude and adjusted prevalence ratios of the effects of the partner's sociodemographic and behavioral variables according to the psychological violence experienced in the last 12 months. After adjustment, it is noted that this type of violence was associated with: education, occupation, use of illicit drugs, alcohol consumption, control and refusal to use condoms ( $\mathrm{p}<0.05$ ). Partners with up to eight years of schooling and no occupation most often practiced psychological violence - with a prevalence ratio (PR) of 1.32; 95\%CI 1.05 - 1.66; RP = 1.38, 95\%CI 1.04-1.83- , respectively. Drug use, alcohol consumption, and condom refusal are associated with an increase of 69.0; 55.0 and 
Table 1. Characteristics of intimate partner. Vitória, Espírito Santo, $2014(\mathrm{n}=938)$.

Characteristics

Gross frequency $(n)$

Relative frequency (\%)

Age (years)

Up to 40

More than 40

\begin{tabular}{|l|r|}
\hline 492 & 52.4 \\
\hline 446 & 47.6 \\
\hline
\end{tabular}

Race/color*

\begin{tabular}{l|l}
\hline White/Caucasian & \\
\hline Black & \\
\hline Brown & \\
\hline Schooling** & \\
\hline
\end{tabular}

\begin{tabular}{|l|l|}
\hline 313 & 34.4 \\
\hline 233 & 25.6 \\
\hline 363 & 39.9 \\
\hline
\end{tabular}

Up to 8 years

More than 8 years

\begin{tabular}{|l|r|}
\hline 303 & 33.8 \\
\hline 592 & 66.1 \\
\hline
\end{tabular}

Occupation

\begin{tabular}{l|l|r}
\hline No & 123 & 13. \\
\hline Yes & 815 & 86.9 \\
\hline
\end{tabular}

Use of illicit drugs

\begin{tabular}{l|c|c}
\hline No & 854 & 91.0 \\
\hline Yes & 59 & 6.3 \\
\hline Does not know & 25 & 2.7 \\
\hline Smoking & &
\end{tabular}

No

\begin{tabular}{l|r}
759 & 80.9
\end{tabular}

Yes

179

19.1

Alcohol consumptio

\begin{tabular}{l|l|l}
\hline No & 396 & 42.2 \\
\hline Yes & 542 & 57.8 \\
\hline Jealous & \multicolumn{2}{|c}{} \\
\hline No & 441 & 47.0 \\
\hline Yes & 497 & 53.0 \\
\hline Controlling & & \\
\hline No & 486 & 51.8 \\
\hline Yes & 452 & 48.2 \\
\hline Refusal to use condom & & \\
\hline No & 714 & 76.1 \\
\hline Yes & 224 & 23.9 \\
\hline
\end{tabular}

${ }^{*} n=909 ;{ }^{* *} n=895$. 
Tabela 2. Prevalência das violências de acordo com características do parceiro.

\begin{tabular}{|c|c|c|c|c|c|c|}
\hline \multirow{2}{*}{ Characteristics } & \multicolumn{2}{|c|}{ Psychological violence } & \multicolumn{2}{|c|}{ Sexual violence } & \multicolumn{2}{|c|}{ Physical violence } \\
\hline & $\mathrm{P}(95 \% \mathrm{Cl})$ & $p$-value & $\mathrm{P}(95 \% \mathrm{Cl})$ & $\mathrm{p}$-value & $\mathrm{P}(95 \% \mathrm{Cl})$ & $p$ \\
\hline \multicolumn{7}{|l|}{ Age (years) } \\
\hline Up to 40 & $23.6(20.0-27.5)$ & \multirow{2}{*}{0.347} & $3.9(2.5-6.0)$ & \multirow{2}{*}{0.035} & $9.8(7.4-12.7)$ & \multirow{2}{*}{0.594} \\
\hline More than 40 & $26.2(22.3-30.5)$ & & $7.0(4.9-9.7)$ & & $8.7(6.4-11.7)$ & \\
\hline \multicolumn{7}{|l|}{ Race/color } \\
\hline $\begin{array}{l}\text { White/ } \\
\text { Caucasian }\end{array}$ & $22.0(17.8-27.0)$ & \multirow{3}{*}{0.116} & $4.8(2.9-7.8)$ & \multirow{3}{*}{0.875} & $6.4(4.1-9.7)$ & \multirow{3}{*}{0.095} \\
\hline Black & $29.6(24.1-35.8)$ & & $5.6(3.3-9.4)$ & & $11.2(7.7-15.9)$ & \\
\hline Brown & $24.0(19.8-28.6)$ & & $4.7(2.9-7.4)$ & & $10.5(7.7-14.1)$ & \\
\hline \multicolumn{7}{|l|}{ Schooling } \\
\hline Up to 8 years & $30.4(25.4-35.8)$ & \multirow[b]{2}{*}{0.008} & $6.3(4.0-9.6)$ & \multirow[b]{2}{*}{0.454} & $12.5(9.2-16.8)$ & \multirow[b]{2}{*}{0.026} \\
\hline $\begin{array}{l}\text { More than } 8 \\
\text { years }\end{array}$ & $22.3(19.1-25.8)$ & & $5.1(3.6-7.2)$ & & $7.9(6.0-10.4)$ & \\
\hline \multicolumn{7}{|l|}{ Occupation } \\
\hline No & $35.0(27.0-43.8)$ & \multirow{2}{*}{0.005} & $9.8(5.6-16.4)$ & \multirow{2}{*}{0.019} & $17.1(11.4-24.8)$ & \multirow{2}{*}{0.001} \\
\hline Yes & $23.3(20.5-26.3)$ & & $4.7(3.4-6.3)$ & & $8.1(6.4-10.2)$ & \\
\hline \multicolumn{7}{|l|}{ Use of illicit drugs } \\
\hline No & $23.6(20.9-26.6)$ & \multirow{3}{*}{$<0.001$} & $5.1(3.8-6.8)$ & \multirow{3}{*}{0.523} & $8.7(6.9-10.7)$ & \multirow{3}{*}{0.007} \\
\hline Yes & $45.8(33.5-58.6)$ & & $8.5(3.5-18.9)$ & & $20.3(11.9-32.6)$ & \\
\hline Does not know & $16.0(6.0-36.2)$ & & $4.0(0.5-24.3)$ & & $4.0(0.5-24.3)$ & \\
\hline \multicolumn{7}{|l|}{ Smoking } \\
\hline No & $22.9(20.1-26.0)$ & \multirow{2}{*}{0.005} & $4.3(3.1-6.0)$ & \multirow{2}{*}{0.006} & $8.2(6.4-10.3)$ & \multirow{2}{*}{0.016} \\
\hline Yes & $33.0(26.4-40.2)$ & & $9.5(6.0-14.8)$ & & $14.0(9.6-19.9)$ & \\
\hline \multicolumn{7}{|c|}{ Alcohol consumption } \\
\hline No & $18.9(15.4-23.1)$ & $<001$ & $3.8(2.3-6.2)$ & P077 & $6.8(4.7-9.8)$ & 7027 \\
\hline Yes & $29.1(25.5-33.1)$ & -0.001 & $6.5(4.7-8.9)$ & 0.072 & $11.1(8.7-14.0)$ & 0.021 \\
\hline Jealous & & & & & & \\
\hline No & $19.9(16.5-23.9)$ & 10000 & $3.8(2.4-6.1)$ & 0050 & $7.3(5.2-10.1)$ & \\
\hline Yes & $29.2(25.3-33.3)$ & 0.001 & $6.6(4.7-9.2)$ & 0.050 & $11.1(8.6-14.1)$ & 0.040 \\
\hline Controlling & & & & & & \\
\hline No & $16.5(13.4-20.0)$ & $<0001$ & $4.1(2.7-6.3)$ & ח 086 & $6.0(4.2-8.5)$ & 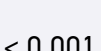 \\
\hline Yes & $33.8(29.6-38.3)$ & -0.001 & $6.6(4.7-9.3)$ & 0.000 & $12.8(10.0-16.2)$ & $<0.001$ \\
\hline Refusal to use con & dom & & & & & \\
\hline No & $21.2(18.3-24.3)$ & & $4.1(2.8-5.8)$ & 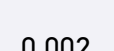 & $7.8(6.1-10.1)$ & 7 \\
\hline Yes & $36.6(30.5-43.1)$ & & $9.4(6.2-14.0)$ & 0.002 & $13.8(9.9-19.0)$ & 0.00 \\
\hline
\end{tabular}

P: prevalence; $95 \% \mathrm{Cl}$ : 95\% confidence interval. 
Table 3. Crude and adjusted analysis of the effects of variables on psychological violence.

\begin{tabular}{|c|c|c|c|c|}
\hline \multirow{2}{*}{ Characteristics } & \multicolumn{2}{|c|}{ Gross analysis } & \multicolumn{2}{|c|}{ Adjusted analysis } \\
\hline & Gross PR $(95 \% \mathrm{Cl})$ & $p$ & Adjusted PR (95\%Cl) & $\mathrm{p}$ \\
\hline \multicolumn{5}{|l|}{ Race/color } \\
\hline White/Caucasian & 1.0 & \multirow{3}{*}{0.199} & 1.0 & \multirow{3}{*}{0.381} \\
\hline Black & $1.34(0.96-1.87)$ & & $1.21(0.90-1.63)$ & \\
\hline Brown & $1.09(0.79-1.49)$ & & $1.03(0.78-1.36)$ & \\
\hline \multicolumn{5}{|l|}{ Schooling } \\
\hline Up to 8 years & $1.36(1.08-1.71)$ & \multirow{2}{*}{0.008} & $1.32(1.05-1.66)$ & \multirow{2}{*}{0.017} \\
\hline More than 8 years & 1.0 & & 1.0 & \\
\hline \multicolumn{5}{|l|}{ Occupation } \\
\hline No & $1.50(1.14-1.97)$ & \multirow{2}{*}{0.003} & $1.38(1.04-1.83)$ & \multirow{2}{*}{0.026} \\
\hline Yes & 1.0 & & 1.0 & \\
\hline \multicolumn{5}{|l|}{ Use of illicit drugs } \\
\hline No & 1.0 & \multirow{3}{*}{0.004} & 1.0 & \multirow{3}{*}{0.004} \\
\hline Yes & $1.93(1.29-2.89)$ & & $1.69(1.22-2.35)$ & \\
\hline Does not know & $0.68(0.25-1.82)$ & & $0.71(0.30-1.70)$ & \\
\hline \multicolumn{5}{|l|}{ Smoking } \\
\hline No & 1.0 & \multirow{2}{*}{0.004} & 1.0 & \multirow{2}{*}{0.656} \\
\hline Yes & $1.44(1.12-1.84)$ & & $1.06(0.81-1.39)$ & \\
\hline \multicolumn{5}{|l|}{ Alcohol consumption } \\
\hline No & 1.0 & \multirow{2}{*}{0.002} & 1.0 & \multirow{2}{*}{$<0.001$} \\
\hline Yes & $1.54(1.17-2.03)$ & & $1.55(1.21-1.99)$ & \\
\hline \multicolumn{5}{|l|}{ Jealous } \\
\hline No & 1.0 & \multirow{2}{*}{0.005} & 1.0 & \multirow{2}{*}{0.957} \\
\hline Yes & $1.46(1.12-1.91)$ & & $0.99(0.78-1.26)$ & \\
\hline \multicolumn{5}{|l|}{ Controlling } \\
\hline No & 1.0 & \multirow{2}{*}{$<0.001$} & 1.0 & \multirow{2}{*}{$<0.001$} \\
\hline Yes & $2.06(1.57-2.69)$ & & $1.96(1.53-2.51)$ & \\
\hline \multicolumn{5}{|c|}{ Refusal to use condom } \\
\hline No & 1.0 & \multirow{2}{*}{$<0.001$} & 1.0 & \multirow{2}{*}{$<0.001$} \\
\hline Yes & $1.73(1.32-2.65)$ & & $1.67(1.33-2.08)$ & \\
\hline
\end{tabular}

Poisson regression with robust variance; PR: prevalence ratio; 95\%: 95\% confidence interval. 
$67.0 \%$, respectively, in the prevalence of psychological victimization. In addition, having a controlling partner was significantly associated with the occurrence of this type of injury $(\mathrm{PR}=1.99 ; 95 \% \mathrm{CI} 1.50-2.62)$.

After adjusting for confounding factors, there is an association between physical violence experienced by women and the following characteristics of the partner: occupation, alcohol consumption, controlling profile and refusal to use condoms in sexual relations. The partner not having occupation and drinking alcohol represents a risk factor $(\mathrm{PR}=2.11 ; 95 \% \mathrm{CI}$ $1.34-3.12 ; \mathrm{PR}=1.61 ; 95 \% \mathrm{CI} 1.05-2.49$, respectively). The prevalence of physical violence is about twice as high among women whose partners are controlling $(\mathrm{p}<0.05)$. For those who refuse to use condoms during sex, there is a $67.0 \%$ increase in the occurrence of physical aggression (Table 4).

Table 5 shows that women whose partner had no occupation had about 2.0 times higher prevalence of sexual victimization $(\mathrm{PR}=1.94 ; 95 \% \mathrm{CI} 1.04-3.64)$. Smoking and refusal to use condoms during sex were associated with 1.94 and 2.18 times the occurrence of sexual violence by the partner $(\mathrm{p}<0.05)$, respectively.

\section{DISCUSSION}

In the present study it is possible to state that the majority of partners are characterized as: under 40 years of age, brown, more than 8 years of study, had paid occupation, did not use drugs or smoked, ingested alcohol, was jealous, but noncontrolling and did not refuse condom use during sexual relations.

It is worth mentioning some characteristics of the men presented here that resemble that found in a study conducted in health facilities in Rio Grande do Norte, where it was evidenced that the users had mean age of 40 years, most of them were brown, ingested alcohol and did not use cigarettes ${ }^{12}$. In addition, a household survey conducted in 2013 with adults living in Maringá, Paraná, showed that most of the educated men had more than eight years of schooling and had work at the time ${ }^{13}$.

With regard to the associations under study, there was a higher prevalence of the occurrence of psychological violence committed by the intimate partner among women whose partners had less education. This result is in line with research conducted with women victims of violence who reported aggression, which showed that the aggressors had low education $^{14}$. Accordingly, a survey conducted in October and November 2003, with 251 users of a basic health unit in Porto Alegre, Rio Grande do Sul, found that men with low education perpetrated more psychological and physical violence ${ }^{15}$. In addition, a household survey conducted in Ghana in 2008 found that women whose partners had higher education had a $45 \%$ lower risk of violence ${ }^{16}$.

Another very relevant finding was the association of the three types of violence with the occupation variable. The intimate partner not having occupation increased the prevalence of women in situations of psychological, physical and sexual violence. A study on the 
Table 4. Gross and adjusted analysis of the effects of variables on physical violence.

\begin{tabular}{|c|c|c|c|c|}
\hline \multirow{2}{*}{ Characteristics } & \multicolumn{2}{|c|}{ Gross analysis } & \multicolumn{2}{|c|}{ Adjusted analysis } \\
\hline & Gross PR $(95 \% \mathrm{Cl})$ & $p$ & Adjusted PR $(95 \% \mathrm{Cl})$ & $\mathrm{p}$ \\
\hline \multicolumn{5}{|l|}{ Race/color } \\
\hline White/Caucasian & 1.0 & \multirow{3}{*}{0.124} & 1.0 & \multirow{3}{*}{0.204} \\
\hline Black & $1.75(0.97-3.13)$ & & $1.62(0.92-2.87)$ & \\
\hline Brown & $1.64(0.95-2.81)$ & & $1.50(0.89-2.54)$ & \\
\hline \multicolumn{5}{|l|}{ Schooling } \\
\hline Up to 8 years & $1.58(1.05-2.37)$ & \multirow{2}{*}{0.027} & $1.46(0.97-2.20)$ & \multirow{2}{*}{0.069} \\
\hline More than 8 years & 1.0 & & 1.0 & \\
\hline \multicolumn{5}{|l|}{ Occupation } \\
\hline No & $2.11(1.34-3.12)$ & \multirow{2}{*}{0.001} & $2.11(1.34-3.12)$ & \multirow{2}{*}{0.001} \\
\hline Yes & 1.0 & & 1.0 & \\
\hline \multicolumn{5}{|l|}{ Use of illict drugs } \\
\hline No & 1.0 & \multirow{3}{*}{0.016} & 1.0 & \multirow{3}{*}{0.088} \\
\hline Yes & $2.34(1.28-4.32)$ & & $1.82(1.03-3.22)$ & \\
\hline Does not know & $0.46(0.06-3.32)$ & & $0.49(0.07-3.25)$ & \\
\hline \multicolumn{5}{|l|}{ Smoking } \\
\hline No & 1.0 & \multirow{2}{*}{0.016} & 1.0 & \multirow{2}{*}{0.071} \\
\hline Yes & $1.71(1.11-2.64)$ & & $1.51(0.96-2.37)$ & \\
\hline \multicolumn{5}{|l|}{ Alcohol consumption } \\
\hline No & 1.0 & \multirow{2}{*}{0.036} & 1.0 & \multirow{2}{*}{0.030} \\
\hline Yes & $1.62(1.04-2.56)$ & & $1.61(1.05-2.49)$ & \\
\hline \multicolumn{5}{|l|}{ Jealous } \\
\hline No & 1.0 & \multirow{2}{*}{0.058} & 1.0 & \multirow{2}{*}{0.605} \\
\hline Yes & $1.52(0.99-2.36)$ & & $1.12(0.72-1.74)$ & \\
\hline \multicolumn{5}{|l|}{ Controlling } \\
\hline No & 1.0 & \multirow{2}{*}{0.001} & 1.0 & \multirow{2}{*}{0.002} \\
\hline Yes & $2.15(1.38-3.36)$ & & $1.98(1.29-3.04)$ & \\
\hline \multicolumn{5}{|c|}{ Refusal to use condom } \\
\hline No & 1.0 & \multirow{2}{*}{0.011} & 1.09 & \multirow{2}{*}{0.014} \\
\hline Yes & $1.76(1.14-2.74)$ & & $1.67(1.11-2.52)$ & \\
\hline
\end{tabular}

Poisson regression with robust variance; PR: prevalence ratio; 95\%: 95\% confidence interval. 
profile of gender violence states that men who do not have an occupation are more likely to commit violence ${ }^{15}$.

In this context, there is greater vulnerability to violence among women from the lower classes. In such a way that, although this event may be present in all social classes, low level of education of the partner and family poverty can predict its occurrence ${ }^{17}$. It is possible that the stress produced by poverty may generate frustrations for men regarding the belief in their social role as a provider ${ }^{18}$. In contrast, it is important to consider that people in poverty, as they are socially vulnerable, report more cases of violence than economically privileged people, since they tend to hide the problem from society ${ }^{19}$.

Table 5. Gross and adjusted analysis of the effects of variables on sexual violence.

\begin{tabular}{|c|c|c|c|c|}
\hline \multirow{2}{*}{ Characteristics } & \multicolumn{2}{|c|}{ Gross analysis } & \multicolumn{2}{|c|}{ Adjusted analysis } \\
\hline & Gross PR $(95 \% \mathrm{Cl})$ & $\mathrm{p}$ & Adjusted PR (95\%Cl) & $p$ \\
\hline \multicolumn{5}{|l|}{ Age (years) } \\
\hline Up to 40 & 1.0 & \multirow{2}{*}{0.039} & 1.0 & \multirow{2}{*}{0.064} \\
\hline More than 40 & $1.80(1.03-3.14)$ & & $1.70(0.97-2.99)$ & \\
\hline \multicolumn{5}{|l|}{ Occupation } \\
\hline No & $2.09(1.12-3.89)$ & \multirow{2}{*}{0.020} & $1.94(1.04-3.64)$ & 0.039 \\
\hline Yes & 1.0 & & 1.0 & 1.0 \\
\hline \multicolumn{5}{|l|}{ Smoking } \\
\hline No & 1.0 & \multirow{2}{*}{0.008} & 1.0 & \multirow{2}{*}{0.020} \\
\hline Yes & $2.18(1.24-3.83)$ & & $1.94(1.11-3.38)$ & \\
\hline \multicolumn{5}{|c|}{ Alcohol consumption } \\
\hline No & 1.0 & \multirow{2}{*}{0.077} & 1.0 & \multirow{2}{*}{0.194} \\
\hline Yes & $1.70(0.94-3.08)$ & & $1.48(0.82-2.66)$ & \\
\hline \multicolumn{5}{|l|}{ Jealous } \\
\hline No & 1.0 & \multirow{2}{*}{0.062} & 1.0 & \multirow{2}{*}{0.362} \\
\hline Yes & $1.72(0.97-3.05)$ & & $1.30(0.74-2.29)$ & \\
\hline \multicolumn{5}{|l|}{ Controlling } \\
\hline No & 1.0 & \multirow{2}{*}{0.089} & 1.0 & \multirow{2}{*}{0.163} \\
\hline Yes & $1.61(0.93-2.80)$ & & $1.48(0.85-2.56)$ & \\
\hline \multicolumn{5}{|c|}{ Refusal to use condom } \\
\hline No & 1.0 & \multirow{2}{*}{0.002} & 1.0 & \multirow{2}{*}{0.005} \\
\hline Yes & $2.31(1.34-3.97)$ & & $2.18(1.27-3.72)$ & \\
\hline
\end{tabular}

Poisson regression with robust variance; PR: prevalence ratio; 95\%: 95\% confidence interval. 
Intimate partner drug use was associated with higher prevalence of violence. The use of illicit drugs by the partner is present in the context of domestic violence, making women even more vulnerable to situations of violence in marital and family relationships ${ }^{20}$. A cross-sectional study conducted in five health units in Ribeirão Preto, São Paulo, in 2008, with 504 women revealed that partners who used illicit drugs committed at least 3 times more violence against women ${ }^{21}$. Similarly, a documentary study conducted at a special women's police station using data from the arrest notices of men detained for assaulting women has shown that drug use can influence family conflict resolution behavior and thus offer higher risk of violence ${ }^{22}$.

Alcohol intake was associated with psychological and physical violence. Data from the I National Survey on Alcohol Consumption Patterns in Brazil showed that four out of ten men reported drinking alcohol during an episode of violence ${ }^{23}$. Research in Ribeirão Preto with health service users, in 2008 , shows that the risk of intimate partner violence increases by $59 \%$ when the partner makes frequent use of alcohol ${ }^{21}$.

These findings make it clear that violence against women is closely related to alcohol consumption. Thus, some actions in the sphere of health services and public policies should be adopted, in addition to those already existing to specifically combat violence, such as the Maria da Penha Law, aiming at establishing protocols and policies at the primary level of health care and specific screening tools not only for victims of domestic violence but also for alcohol dependent persons and/or their partner ${ }^{23}$.

Regarding the controlling characteristic of the intimate partner, a study shows that women who considered their partners controlling were 3.8 times more likely to suffer violence $^{21}$. In vulnerable regions of the Federal District, when asked about their partners' controlling behavior, $36.0 \%$ of women stated that their partners sought to prevent them from visiting or seeing friends, $22.0 \%$ restricted their contact with family members and $45.0 \%$ of them wanted to know where they were at all times. Controlling behavior was associated with the perpetration of physical, sexual and psychological violence ${ }^{24}$, as presented in this research.

As for the refusal to use condoms during sexual intercourse, this has been associated with higher prevalence of physical violence, being a phenomenon that occurs when there is a predominance of machismo in relationships, that is, unequal relationships, which makes it difficult for women to negotiate the use of condoms ${ }^{15}$.

A study conducted in Haiti showed that aggression against women in case of refusal to have sex was associated with lower condom use. Also in this research, 44\% of HIV-positive men did not use condoms during the last time they had $\operatorname{sex}^{25}$. Refusal to use condoms during sex constitutes a risk to the occurrence of sexually transmitted infections $(\mathrm{STI})^{25}$.

Controlling behavior of the partner and their refusal to use condoms reflect on the relations of gender inequality. These findings suggest a search for restoration of power or prevention of loss of power in situations in which male and female attributions are changing, leading to conflicting relationships ${ }^{26}$. The violence practiced by the partner against women 
imprints subordination, domination, inequality of privileges, rights and duties, highlighting gender-based violence ${ }^{27}$.

Finally, there is a gap in scientific production about men who perpetrate violence against women. The data found here are of great relevance to better understand the aspects that permeate this phenomenon, as well as to provide elements for the elaboration of attention and prevention policies. Note the importance of the health sector in promoting actions aimed at preventing the use of licit/illicit drugs and encouraging the use of condoms in sexual relations, focusing on women's empowerment.

Such attitudes are believed to contribute as strategies to prevent and confront violence against women. However, it is important to highlight that this confrontation requires an intersectoral articulation of services, as well as the training of professionals so that women are fully served ${ }^{28}$. From this perspective, health professionals should understand that care for women in situations of violence goes beyond screening and treatment, requiring careful listening and adequate reception ${ }^{27}$.

Regarding the limitations of the present study, firstly, the type of research design stands out. As it is a cross-sectional study, it is not possible to determine causal and temporal relationships, but to explore the relationships between outcomes and the variables being study, not assessing risk and protection factors. However, it is worth mentioning that the findings evidenced in this research are similar to other studies, also of cross-sectional nature, and reinforce the need for studies of this theme, of the longitudinal type, that allow establishing relationships of temporality and possible cause.

Another limitation that deserves to be pointed out is the way information is obtained, considering that the partner data were obtained from the women interviewed and, if they did not mention exactly what would be pointed out by men, it is suggested that the measures could be underestimated. On the other hand, women who have suffered violence may overestimate the suffering and thus also overestimate these relationships. However, the methodology adopted is similar to other studies on this subject ${ }^{14,20}$.

\section{CONCLUSION}

The results of the association between violence against women and intimate partner sociodemographic and behavioral characteristics show that certain intimate partner characteristics, such as behavioral ones, are associated with higher prevalence of violence situations, whether psychological, physical or sexual.

These data highlight the importance of primary care health professionals acting together with other sectors such as education and security. It is necessary to develop joint actions in the fight against alcohol and other drugs, as well as addressing gender issues, in order to strengthen and promote greater empowerment of women, so that men respectfully understand equal rights and the different roles of women in society. 


\section{REFERENCES}

1. Bandeira LM. Violência de gênero: a construção de um campo teórico e de investigação. Soc Estado 2014; 29(2): 449-69. http://dx.doi.org/10.1590/ S0102-69922014000200008

2. Lucena KDT, Deininger LSC, Coelho HFC, Monteiro ACC, Vianna RPT, Nascimento JA. Analysis of the cycle of domestic violence against women. J Hum Growth Dev 2016; 26(2): 139-46. http:/ / dx.doi.org/10.7322/ jhgd.119238

3. Albuquerque Netto L, Moura MAV, Queiroz ABA, Leite FMC, Silva GF. Isolation of women in situation of violence by intimate partner: a social network condition. Esc Anna Nery 2017; 21(1): 1-8. http:/ / dx.doi.org/10.5935/1414-8145.20170007

4. World Health Organization. Responding to intimate partner violence and sexual violence against women: WHO clinical and policy guidelines. Genebra: WHO; 2013.

5. World Health Organization. Global and regional estimates of violence against women: prevalence and health effects of intimate partner violence and nonpartner sexual violence. Genebra: WHO; 2013.

6. Venturi G, Recamán M, Oliveira S, editores. A mulher brasileira nos espaços público e privado. São Paulo: Fundação Perseu Abramo; 2004.

7. Leite FMC, Amorim MHC, Wehrmeister FC, Gigante DP. Violência contra a mulher em Vitória, Espírito Santo, Brasil. Rev Saúde Pública 2017; 51: 33. http:// dx.doi.org/10.1590/ S1518-8787.2017051006815

8. Silva ACLG, Coelho EBS, Moretti-Pires RO. O que se sabe sobre o homem autor de violência contra a parceira íntima: uma revisão sistemática. Rev Panam Salud Publica 2014; 35(4): 278-83.

9. Silva ACLG, Coelho EBS, Njaine K. Conjugal violence: controversies in the reports of intimate partners in police investigations. Ciênc Saúde Coletiva 2014; 19(4): 1255-62. http://dx.doi. org/10.1590/1413-81232014194.01202013

10. Schraiber LB, Latorre MRDO, França Jr. I, Segri NJ, D'Oliveira AFPL. Validity of the WHO VAW study instrument for estimating gender-based violence against women. Rev Saúde Pública 2010; 44(4): 1-9. http://dx.doi.org/10.1590/ S0034-89102010000400009

11. Organização Mundial de Saúde. Prevenção da violência sexual e da violência pelo parceiro íntimo contra a mulher: ação e produção de evidência. São Paulo: OMS; 2012
12. Santiago FP, Souza PRF, Machado FCA, Fernandes ERL. Perfil de homens na atenção primária à saúde. HOLOS 2015; 5: 430-9. http:/ / dx.doi.org/10.15628/ holos.2015.3214

13. Arruda GO, Mathias TAF, Marcon SS. Prevalência e fatores associados à utilização de serviços públicos de saúde por homens adultos. Ciênc Saúde Coletiva 2017; 22(1): 279-90. http:/ / dx.doi. org/10.1590/1413-81232017221.20532015

14. Leite FMC, Bravim LR, Lima EFA, Primo CC. Violência contra a mulher: caracterizando a vítima, a agressão e o autor. Rev Pesq Cuid Fundam 2015; 7(1): 218191. http:/ / dx.doi.org/10.9789/2175-5361.2015. v7i1.2181-2191

15. KronbauerJFD, Meneghel SN. Profile of gender violence by intimate partners. Rev Saúde Pública 2005; 39(5): 1-6. http: / / dx.doi.org/10.1590/S0034-89102005000500001

16. Adjah ESO, Agbemafle I. Determinants of domestic violence against women in Ghana. BMC Public Health 2016; 16(1): 1-9. http://dx.doi.org/10.1186/ s12889-016-3041-x

17. Krug EG, Dalhberg LL, Mercy JA, Zwi AB, Lozano $\mathrm{R}$, editors. Informe mundial sobre la violencia y la salud. Genebra: OMS; 2003.

18. Heise LL. Violence against women: an integrated, ecological framework. Rev Violence Against Women 1998; 4(3): 262-90. http://dx.doi. org/10.1177/1077801298004003002

19. Dossi AP, Saliba O, Garbin CAS, Garbin AJI. Epidemiological profile of domestic violence: complaints of aggression filed in a city in São Paulo State, Brazil, from 2001 to 2005. Cad Saúde Pública 2008; 24(8): 1939-52. http:// dx.doi.org/10.1590/ S0102-311X2008000800022

20. Vieira LB, Cortes LF, Padoin SMM, Souza IEO, Paula CC, Terra MG. Abuso de álcool e drogas e violência contra as mulheres: denúncias de vividos. Rev Bras Enferm 2014; 67(3): 366-72. http://dx.doi. org/10.5935/0034-7167.20140048

21. Vieira EM, Perdona GSC, Santos MA. Factors associated with intimate partner physical violence among health service users. Rev Saúde Pública 2011; 45(4): 1-8. http: / / dx.doi.org/10.1590/S0034-89102011005000034

22. Madureira AB, Raimondo ML, Ferraz MIR, Marcovicz GV, Labronici LM, Mantovani MF. Profile of men who commit violence against women who are arrested in delicto flagrante: contributions to confronting the phenomenon. Esc Anna Nery 2014; 18(4): 600-6. http:/ / dx.doi.org/10.5935/1414-8145.20140085 
23. Zaleski M, Pinsky I, Laranjeira R, RamisettyMikler S, Caetano R. Intimate partner violence and alcohol consumption. Rev Saúde Pública 2010; 44(1): 1-7. http://dx.doi.org/10.1590/ S0034-89102010000100006

24. Moura LBA, Gandolfi L, Vasconcelos AMN, Pratesi $\mathrm{R}$. Intimate partner violence against women in an economically vulnerable urban area, Central-West Brazil. Rev Saúde Pública 2009; 43(6): 944-53. http: / / dx.doi.org/10.1590/S0034-89102009005000069

25. Conserve DF, Whembolua GL, Surkan PJ. Attitudes Toward Intimate Partner Violence and Associations With Condom Use Among Men in Haiti. J Interpers Violence 2014; 31(6): 989-1006. http:// dx.doi. org/10.1177/0886260514564065

26. Schraiber LB, D’Oliveira AFPL, França-Junior I. Intimate partner sexual violence among men and women in urban Brazil, 2005. Rev Saúde Pública 2008; 42(Supl. 1): 1-10. http://dx.doi.org/10.1590/ S0034-89102008000800015
27. Borburema TLR, Pacheco AP, Nunes AA, Moré CLOO, Krenkel S. Violência contra mulher em contexto de vulnerabilidade social na Atenção Primária: registro de violência em prontuários. Rev Bras Med Fam Comunidade 2017; 12(39): 1-13. http:// dx.doi. org/10.5712/rbmfc12(39)1460

28. Menezes PRM, Lima IS, Correia CM, Souza SS, Erdmann AL, Gomes NP. Process of dealing with violence against women: intersectoral coordination and full attention. Saúde Soc 2014; 23(3): 778-86. http: / / dx.doi.org/10.1590/S0104-12902014000300004

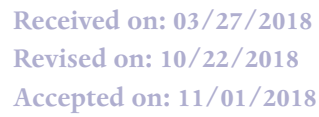

Author's contributions: Study design and planning: FMCL, DPG, MHCA. Data collection, analysis and interpretation: FMCL. Writing of the manuscript: FMCL, MAL. Critical revision of the manuscript: DPG, MHCA, ELNM. 